\title{
Analysis of the Neogene Stretava Formation in the selected parts of the East Slovakian Basin
}

\author{
Igor Ďuriška
}

Technical University of Košice, Faculty of Mining, Ecology, Process Control and Geotechnologies, Institute of Geosciences; Letná 9, 04200 Košice, Slovakia

(C) 2015 Authors. This is an open access publication, which can be used, distributed and reproduced in any medium according to the Creative Commons CC-BY 4.0 License requiring that the original work has been properly cited.

The Lower Sarmatian Stretava Formation consists of clay-, sand- and gravel-sized deposits with volcanoclastics derived from the volcanic Slanské vrchy Mts. In the western margin of the basin, the formation consists of the coarse-grained deposits named as Košice Gravel, deposited in deltaic and inner shelf environment (Karoli et al. 1989). The deltaic sediments were also deposited on the northern margin of the basin, where Laborec and Topla rivers entered the sea (Janočko et al. 2003).

The main aim of the study is to show the geometry of the Lower Sarmatian deposits which can be used for both paleogeographical studies and estimation of the hydrocarbon potential of the formation. A comprehensive approach including connection of vertical seismic analysis, field study of the outcrops and analysis of the well data was used in this study. Presented study was focused on the deposits of the Stretava Formaton in the SE part of the Presov Depression and the central western part of the Trebisov Depression that both are part of the East Slovakian Basin.

\section{OUTCROP ANALYSIS}

The field study was performed in the area of Košice (locality Nad jazerom), located on the western margin of the East Slovakian Basin. The outcrop analysis, which included facies analysis of logged sediments resulted in interpretation of following depositional environments: 1. delta plain, 2. offshore-transition zone, 3 . shoreface. The delta plain environment is typical by distributary channels incised into flood-plain deposits. The channel sediments consists of pebble and cobble sized gravel with well developed channel lag facies. The delta plain sediments are represented by silts with thin layers of sand. Sediments of channel levee and crevasse splay sediments were also documented based on their facies association characteristics; the channel levee sediments are typical by coarse sands fining upward into silts and crevasse splay deposits are formed by pebble sized gravel and sands. The transition of the deltaic and shoreface deposits into offshore-transition deposits shows a rapid increase of the accommodation space suggesting both sea level rise and basin floor subsidence.

\section{SEISMIC ANALYSIS}

The Stretava Fm., which is almost extended in the entire basin, can be studied by several seismic profiles. The deposition of the formation started with a regional unconformity related to the new sea transgression observable on several seismic profiles by onlaps (profiles from the Trebišov depression). The profiles also show the changes in the thickness of the deposits in the Prešov and the 
Trebišov depressions. Two system tracts are visible in the seismic package analysed: the transgressive system tract (TST) and the highstand system tract (HST) with the maximum flooding surface (MFS) between them.

These tracts bracket several types of sediment geometries, which are described in more detail in the presentation.

\section{REFERENCES}

Janočko J., Elečko M., Karoli S., Konečný V., Kováč M., Nagy A., Vass D., Jacko S. \& Kaličiak M., 2003: Sedimentary evolution of the Tertiary basins of the Western Carpathian. Mineralia Slovaca, 35, 3-4, 211-254.

Karoli S., Janočko J. \& Spišák Z., 1989. K problému košickej štrkovej formácie, kvartéru a svahových deformácií pri východnom okraji Košíc. Regionálna geológia Západných Karpat, 25, 17-22. 